\title{
Analysis of Enterprise Profile and Composition of Solid Waste Generated in the Informal Sector of Gweru, Zimbabwe
}

\author{
Steven Jerie \\ Department of Geography and Environmental Studies, Midlands State University, Gweru, Zimbabwe \\ Correspondence should be addressed to Steven Jerie; steve.jere@gmail.com
}

Received 24 February 2014; Accepted 19 May 2014; Published 11 June 2014

Academic Editor: David Bolzonella

Copyright (c) 2014 Steven Jerie. This is an open access article distributed under the Creative Commons Attribution License, which permits unrestricted use, distribution, and reproduction in any medium, provided the original work is properly cited.

\begin{abstract}
This paper examines the characteristics of solid waste generated in the informal sector enterprises of Gweru, the third largest city in Zimbabwe. Samples from the informal sector enterprises were collected in plastic bags and labelled with unique identity marks. The segregated components were measured to determine percentages of total weight of a sample. The data collected during the two seasons were analysed statistically using ANOVA to identify key similarities and differences. The major components of the waste stream include food and vegetable wastes in the market areas (from 18 to $51 \%$ of total weight), metals in the industrial areas (from 19 to 36\%), and paper in the residential suburbs and markets (9-11\% of total weight). The biodegradable waste stream dominates in the market areas of Kudzanai and Kombayi where it constitutes an average of $57.1 \%$ of waste generated in these areas. Establishing biodegradability of solid waste is essential because the majority of environmental and health problems associated with waste generated in the enterprises are caused by the biodegradable components. In order to come up with a sustainable and comprehensive waste management plan for the informal sector of Gweru, an up-to-date database on the composition and characteristics of the waste is a primary requirement.
\end{abstract}

\section{Introduction}

The cornerstone of successful planning for a waste management program is the availability of reliable information about the quantity and type of material being generated and an understanding about how much of that material collection managers can expect to prevent or capture. Effective waste management through waste composition studies is thus vital for a number of reasons including the need to estimate material potential, to identify sources of component generation, to facilitate design of processing equipment, to estimate physical, chemical, and thermal properties of waste, and to maintain compliance with national and international laws.

It is universally accepted that the quantity, characteristics, and composition of refuse vary according to socioeconomic status, food habits, local customs, geographical location, occupations, and climatic conditions [1-6]. Wastes are characterised on the basis of weight generated in kilograms per person per day ( $\mathrm{kg} /$ person-day) and density in cubic metres and composition [1,7-11]. In developing countries, there is little data on generation and types of waste. Generally the relationship between municipal solid waste generation and factors varies with the developmental stage of a nation. In a developing country, economic development directly affects the quantity of waste generated. In India, the living standard and the level of urbanisation have played an important role in municipal solid waste generation [12]. In Thailand, the quantity of generated solid waste has been attributed mainly to population and economic growth [13]. A socioeconomic analysis of waste generation in Brazil indicated that the upper-income class brought about more recyclable solid waste than the low income class [14]. In contrast, a weak correlation exists between economic development and waste generation for developed countries; per capita waste generation actually decreases as economic development increases in the wealthiest countries [15]. According to reports, the per capita waste generation decreased by 30\% from 1977/1978 to 1992 in Dublin while the economy increased during this period [16]. The per capita production of solid waste in New York City peaked in 1940, was at its lowest in the 1960s, and remained steady after the 1980s [17]. Sokka et al. [18] have suggested that the relationship between gross domestic 
product (GDP) growth and generation of solid waste was not as clear cut as assumed in Finland. Compared to GDP growth the growth in solid waste generation was slower. In addition lifestyle, change of seasons, and population also affect solid waste generation [19]. In China, most published work has focused on the relationship between waste production and socioeconomic factors in a special area and province or within a specific time period of months (e.g., [20-23]). In Zimbabwe, the data is unreliable and difficult to obtain.

Wastes are characterised on the basis of weight generated in kilograms per person per day ( $\mathrm{kg} /$ person-day), density in cubic metres and composition [10, 21, 24, 25]. In developing countries, there is little data on generation and types of waste. Quantities of waste are in most cases lower in the developing countries because of a lower propensity to consume as well as extensive scavenging and salvage by beggars and the very poor [26-29]. Densities of wastes are higher in developing countries because of the lower amounts of paper, plastic, glass, and packaging materials and hence a greater concentration of putrescible matter [16, 25, 28-32].

Solid waste management services are inadequately provided in many parts of the developing world. The involvement of the formal private sector in the management of solid waste remains low due to a number of reasons that hinge mainly on the lack of adequate finance [33]. This has resulted in waste collection and material recovery activities being taken over by the informal sector. A number of studies confirm that the informal sector plays a more important role than the formal sector in solid waste recovery in most parts of the developing countries [34-38]. Those involved in waste management include waste pickers in dumpsites and at communal waste collection points, informal waste collectors, itinerant waste buyers, small tuck-shop dealers, and collection crews of garbage trucks [33]. Studies have also revealed that the recycling activities in the informal sector may reduce the cost of solid waste management, provide livelihood for the urban poor, and can lead to positive or negative effects on the environment [34, 39-41]. The aim of this paper is to analyse the characteristics of informal sector enterprises of Gweru in Zimbabwe and the types and quantities of solid waste generated in these enterprises. The informal sector of Gweru was targeted for this study since it now employs over $70 \%$ of economically active population due to economic implosion that occurred in Zimbabwe between 2000 and 2009.

\section{Methodology}

The study involved all the 601 organised informal sector enterprises in Gweru, the third largest city in Zimbabwe whose location is shown in Figure 1. The enterprises are located in Monomotapa high density suburb, Shamrock Park medium density suburb, Mkoba high density Suburb, Ascot high Density Suburb, Kudzanai market, and Kombayi market. Focus was on these areas because of the large concentrations of informal enterprises characterised by a diverse range of enterprises that include retail, service, repair, manufacturing, and construction activities. In Monomotapa 47 out of 51 enterprises agreed to participate in the survey. At Shamrock
Park there was a combination of informal sector enterprises and small scale and medium scale enterprises. All the 57 informal sector enterprises were selected to participate in the survey and these were those with less than 10 employees and the small scale and medium scale enterprises were left out since they did not meet the criteria for defining informal sector enterprises. All the 182 enterprises at Kudzanai who were allocated with stalls from which they operated were involved in this study and participated with keen interest and the majority are retailers of food and clothing. The other market area near the city centre is at Kombayi and all the 29 informal enterprises who were allocated stalls participated in the study and as at Kudzanai these are mainly food and clothing retailers. In Mkoba and Ascot high density suburbs the majority of enterprise operators participated in the survey and the very few who declined to participate were either suspicious or simply uncooperative. Out of a total of 229 enterprises in Mkoba, 224 participated from the sections of Mkoba 6, Mkoba 14, and Mkoba 16 and in Ascot a total of 50 out of 53 enterprises participated in the study. All in all 589 enterprises participated in the questionnaire survey and these were categorised as shown in Table 1.

Data collection for the waste compositional study followed the traditional material based classification adopted by Burnley [16]. The samples from the informal sector enterprises were collected in plastic bags and labelled with unique identity marks. These are to be segregated using the predesigned 14-character template after Chung and Poon [21] and Dahlén and Lagerkvist [10]. The segregated components were weighed to determine weights as percentages of total weight of a sample. The data collected during the dry season and wet season were analysed statistically using ANOVA to identify key similarities and differences. The possible sources of error in solid waste sampling procedure have been listed by Dahlén and Lagerkvist [10] to include errors due to spatial periodic variations. Notwithstanding, possible error sources during the measurement would include sample preparation, increment extraction, grouping, segregation, and fundamental errors.

In the industrial, high density areas and market areas $50 \mathrm{~kg}$ of waste was sampled monthly for six months and the bags were sorted one by one with the aid of research assistants. A simple balance was used for weighing the samples and segregated components under site conditions; the sum of weights of segregated components sometimes differed from the initial weight of entire sample before segregation. On average a net gain or loss of $0.2 \%$ to $0.5 \%$ was observed with rare discrepancies up to $4.3 \%$ in the wet season. This compares reasonably with figures obtained by Chung and Poon [21], 6\%, and Parizean et al. [25], 2.7\%.

\section{Results and Discussion}

3.1. A Typology of Informal Sector Operations in Gweru. The informal sector in the city of Gweru is characterised by a diverse range of small scale activities and microactivities without corresponding institutions such as banks and with none of the opportunities for growth and accumulation, which typify formal small scale enterprises. Firstly, 


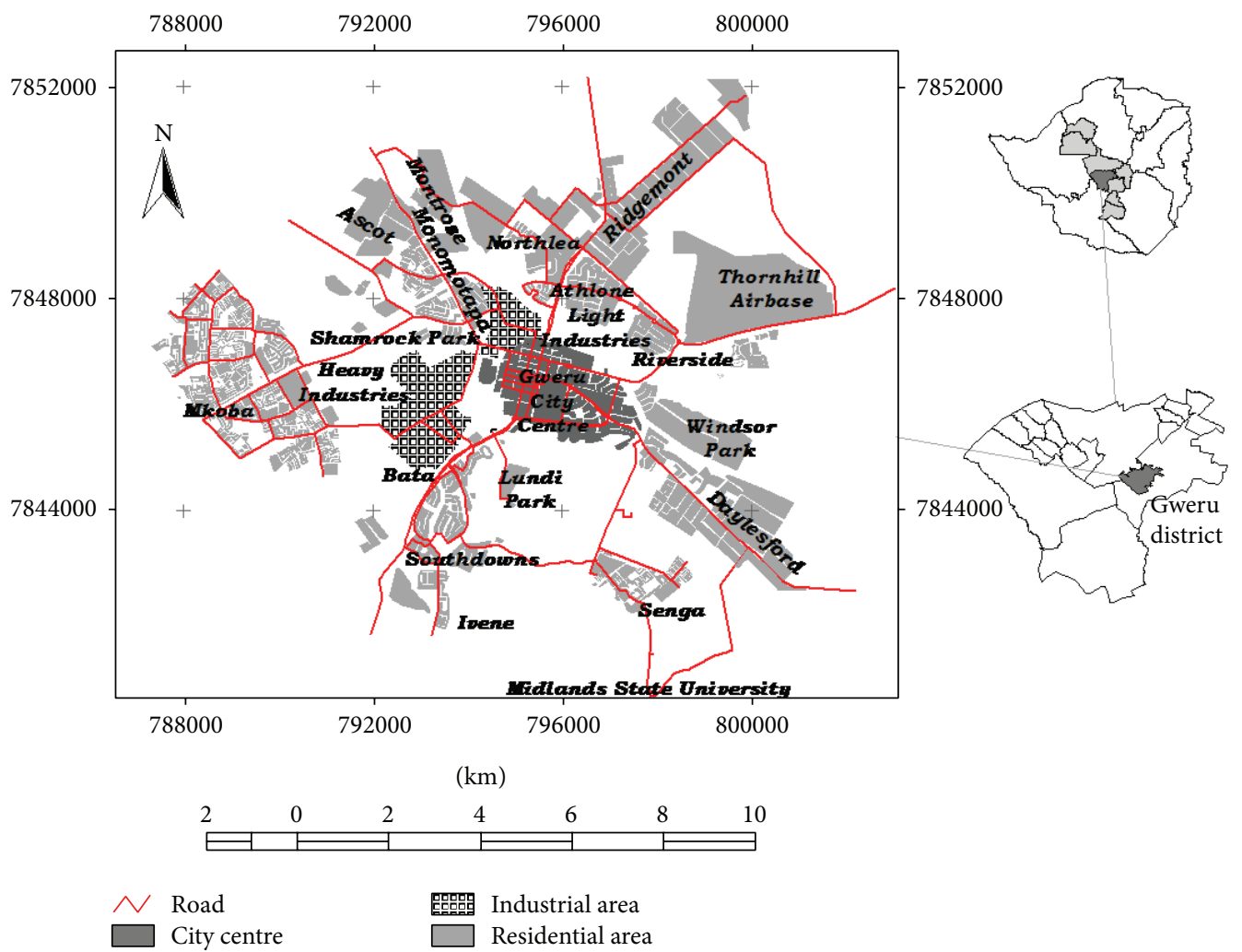

Figure 1

TABLE 1: Categories of informal enterprises in the six spatial locations.

\begin{tabular}{lcccccc}
\hline \multirow{2}{*}{ Spatial location } & & \multicolumn{2}{c}{ Enterprise category } & Total \\
& Retail & Service & Repair & Manufacturing & Construction \\
\hline Monomotapa & 7 & 3 & 11 & 17 & 9 & 47 \\
Shamrock Park & 6 & 1 & 8 & 18 & 24 \\
Kudzanai & 143 & 11 & 13 & 0 & 3 & 12 \\
Kombayi market & 24 & 1 & 10 & 7 & 2 & 1 \\
Ascot & 25 & 7 & 40 & 59 & 50 \\
Mkoba 6, 14, 16 & 74 & 31 & 84 & 113 & 29 \\
\hline Total & 279 & 54 & & & 59 \\
\hline
\end{tabular}

the operations are grouped according to spatial location where three basic forms can be identified. These include the neighbourhood-based as in the case of Ascot and Mkoba high density suburbs, those that take place in the industrial sites or their vicinity (Shamrock Park) and those that take place close to the central business district (CBD) at Kudzanai market and bus terminus. The neighbourhood-based operations take place near the home and these are residence-tied. Examples include women who sell vegetables at roadsides in the high density residential suburbs of Mkoba, Ascot, and Monomotapa. This phenomenon boomed in the post- economic structural adjustment era in Gweru whereby many operators left designated market stalls and located at the "more accessible" roadsides.

The second form is characterised by entrepreneurs close to light industrial sites as at Monomotapa and Shamrock
Park. These are somewhat well organised and involve activities such as motor mechanics, welding, spray painting, construction, panel beating, tinsmiths, plumbing, food shops, and hairdressers. These operators are complemented by those who specialise in providing luncheon and other foodstuffs to the industrial workers and they normally travel on foot to the places of operation. When they carry goods such as bread, buns, soft drinks, or luncheon for sale, they usually hire transporters and these may be push-cart operators who are informal transporters themselves. Some operators are commuters and they travel from other residential areas in town. What attracts them to the place of operation in the industrial areas are agglomeration economies of scale of having many customers from different industrial firms buying cheap lunch or breakfast from their enterprises. Some operators in the informal sector of Gweru are also attracted to the central 
TABLE 2: Characteristics of activities associated with the informal enterprises.

\begin{tabular}{|c|c|}
\hline Enterprise & Main activities \\
\hline Motor mechanics & $\begin{array}{l}\text { Panel beating and body works, autoelectrical repairs, bumper fitting, gearbox repairs, wheel alignment, } \\
\text { pressure checking, spray painting, car wash and repair, and general service of motor vehicles. }\end{array}$ \\
\hline Welding and metal works & $\begin{array}{l}\text { Production of burglar bars, window and door frames, gates, fences, scotch carts, ploughs, door screens, } \\
\text { chicken cages, French doors, cutting metal, soldering, cutting metals, keys, gates, hoes, car exhausts, } \\
\text { minibus seats, grinding mills and their stands, braai stands, pots and soldering, coating, fixing, lining, } \\
\text { grinding, and reverting. }\end{array}$ \\
\hline Carpentry & $\begin{array}{l}\text { Production and repair of furniture such as lounge suites, chairs, stools, kitchen units, tables, wardrobes, } \\
\text { beds, coffee tables, kitchen dressers, coffins, and/or sale of timber. }\end{array}$ \\
\hline Tinsmiths & $\begin{array}{l}\text { Manufacture of buckets, dishes, plates, dust pans letter boxes, chicken fowl equipment, and other metal } \\
\text { products such as paraffin lamps. }\end{array}$ \\
\hline $\begin{array}{l}\text { Electrical and mechanical } \\
\text { engineering }\end{array}$ & Rewinding, electrical motors, underground ventilation, and fabrication. \\
\hline $\begin{array}{l}\text { Borehole } \\
\text { installation/plumbing }\end{array}$ & $\begin{array}{l}\text { Installation and servicing of boreholes and water tanks/production and sale of plumbing equipment; } \\
\text { provision of plumbing services. }\end{array}$ \\
\hline Tyres & Mending, polishing, and sale of tyres. \\
\hline Spare parts & $\begin{array}{l}\text { Purchase and sale of spare parts that range from motor vehicle to household machinery such as } \\
\text { washing machine, including hardware. }\end{array}$ \\
\hline Plastics, drums, and baskets & Sale of plastics, empty drums, and baskets. \\
\hline Upholstery & Refurbishing of furniture, seat covers, and other equipment. \\
\hline Hairdresser/barber & Braiding, trimming, weaving, locking hair, freezing, blowing and haircuts, retouching, and shaving. \\
\hline Tailoring/dressmaking & $\begin{array}{l}\text { Production of uniforms, suits, bedspreads, curtains, suits, jackets, tracksuits, African attire, knitting } \\
\text { jerseys, cutting, designing, pleating, patching, embroidering, ironing, and stitching. }\end{array}$ \\
\hline $\begin{array}{l}\text { Brick } \\
\text { moulding/tombstones }\end{array}$ & Production of bricks for construction purposes and tombstones. \\
\hline Milling/bakeries & Production of maize meal, chicken feeds, bread, and related items. \\
\hline Repairs & $\begin{array}{l}\text { Repair of bicycles and motor cycles, electrical gadgets such as stoves, radios, televisions, DVDs, } \\
\text { refrigerators, cell phones, shoe mending, tyres, boreholes, generators, and furniture. }\end{array}$ \\
\hline Timber sales & Sale of timber and thatch for building and other uses. \\
\hline Flea markets & Sale of clothes, electronics, and other goods. \\
\hline Food catering/vending & Sale of foodstuffs and fruits and vegetables; baking and cooking food. \\
\hline
\end{tabular}

business district because of the many advantages that it enjoys relative to other parts of Gweru city centre. In the $\mathrm{CBD}$ the items sold are of a diverse kind; hence operators take advantage of the diverse mix of the threshold supporting the goods and services on offer. Table 2 shows the characteristics of the enterprises in the informal sector of the areas under study.

The main enterprises in the home industries of Gweru focus on five major concentrations in the high density areas of Monomotapa, Mkoba, and Ascot as well as the major market areas close to the city centre (at the Kudzanai bus rank and Kombayi market area) and at Shamrock Park. Almost half of the enterprises (47.4\%) are involved with the retail sector, followed by manufacturing (19.2\%), repair (14.3\%), and construction sector $(10 \%)$ with the least number of enterprises engaging in the service sector $(9.2 \%)$. The distribution of enterprises, however, varies with spatial area. When considering the five spatial areas, the retail sector dominates at Kudzanai market and bus rank as well as at Kombayi market and in Mkoba and Ascot high density suburbs where the main activities involve selling vegetables, clothing imported from neighbouring countries (especially South Africa, Botswana, and Zambia), and other foodstuffs such as sweets, cool drinks, and lunches. The manufacturing and construction sectors on the other hand dominate at Shamrock Park and Monomotapa where there is a concentration of somewhat organised small scale enterprises that are involved in activities such as metal fabrication, welding, carpentry, tinsmithing, panel beating, spray painting, brick moulding, and motor mechanics. The enterprises at Monomotapa are essentially focused on providing affordable goods such as furniture, buckets, tins, and tombstones to the low income groups in the areas where they operate from. On the other hand the enterprises at Shamrock Park may manufacture and construct goods similar to those at Monomotapa, but on a slightly higher order to include boreholes, rewinding, and other services such as electrical and mechanical engineering. Employees in the construction activities dominate in number at Shamrock Park $(42.1 \%)$ followed by Monomotapa (19.1\%) and least at Ascot (2\%) where retail functions dominate. When considering the spatial areas it can be noted that employees in repair activities are most dominant at Monomotapa where they constitute $23.4 \%$ of the total followed by Ascot (20\%) as shown in. However, among particular functions repair functions are the second most dominant at Monomotapa, Kudzanai, and Ascot 
TABLE 3: Enterprise profile by employment category (\%).

\begin{tabular}{|c|c|c|c|c|c|}
\hline Employment category & Monomotapa & $\begin{array}{c}\text { Shamrock } \\
\text { park }\end{array}$ & Mkoba & Kudzanai/Kombayi & Ascot \\
\hline $\begin{array}{l}\text { Retail } \\
\text { Food catering, vegetable sales, flea markets, timber } \\
\text { sales, thatch sales, spare parts, plastics, drums, and } \\
\text { basket sales }\end{array}$ & 14.9 & 10.5 & 33 & 79.1 & 50 \\
\hline $\begin{array}{l}\text { Service } \\
\text { Hairdresser/barber }\end{array}$ & 6.4 & 1.8 & 13.8 & 5.7 & 14 \\
\hline $\begin{array}{l}\text { Repair } \\
\text { Motor mechanic, shoe repairman, bicycle mechanic, } \\
\text { electrician, tyre repairer, computer technician, cell } \\
\text { phone repairer, and plumber }\end{array}$ & 23.4 & 14 & 17.9 & 7.1 & 20 \\
\hline $\begin{array}{l}\text { Manufacturing } \\
\text { Carpenter/furniture maker, tinsmith, } \\
\text { tailor/dressmaker, brick maker, miller/baker, graphic } \\
\text { designer, upholstery, brick moulding, tombstones }\end{array}$ & 36.2 & 31.6 & 26.3 & 5.7 & 14 \\
\hline $\begin{array}{l}\text { Construction } \\
\text { Welder, metal worker/steel fabricator, electrical and } \\
\text { mechanical engineer, plumber, borehole installer, } \\
\text { builder, painter }\end{array}$ & 19.1 & 42.1 & 8.9 & 2.4 & 2 \\
\hline
\end{tabular}

showing the importance of this activity to the residents of the nearby residential areas. The repair functions involve shoe mending, repair of electrical and electronic equipment, and motor mechanics. The service category is the smallest among the spatial areas; however, it is most dominant in Mkoba (13.8\%) and at Monomotapa (6.4\%) and is mainly associated with barber shops and hair salons.

A Chi-Square test was used to test the degree of association between enterprise activity and spatial location based on the following hypothesis:

$\mathrm{H}_{0}$ : there is no association between enterprise activity and spatial area.

The test results from Table 3 reveal that $P<0.05$ and hence the null hypothesis is rejected meaning that the enterprise categories are closely related to spatial areas supporting the discussion in the preceding section where particular activities tend to dominate in certain locations.

Activities such as carpentry and tinsmith are labour intensive and have an average number of 7 and 6 employees, respectively. Carpentry and tinsmith are family owned and labour is thus readily available and cheap. The production of large items such as wardrobes, beds, tables, chairs, and kitchen units requires a large labour force. At the same time the amount of goods produced influences the amount of waste generated in a particular enterprise. Motor mechanics, spare parts, tyre, food vending, and vegetable vending are not labour intensive and have an average number of employees varying between 1 and 4. Motor mechanics, spare parts, and tyre enterprises are specialised in nature and do not require a large labour force when compared to carpentry or tinsmith activities. The quantity of waste generated by the spare parts enterprises especially reflects the nature of their activities.

The estimates of incomes are difficult to verify since most of the operators do not keep any records of incomes and expenditure and use the daily earnings immediately and the inevitable fluctuations in earnings according to season. Another problem associated with the use of income data gathered in the enterprises relates to the failure of most respondents to distinguish between net profit and total earnings.

Welders constitute the greatest number of enterprises at Monomotapa and Mambo accounting for 29\% of total enterprises in these areas. Welders are able to change the type of goods they manufacture seasonally; for example, during the rainy season (October to February) they concentrate on the production of scotch carts and ploughs and around April, after harvest, they produce window and door frames. Their production is seasonal because their clients have their homes in rural areas and supplement their incomes by agricultural production. During the other times they produce other items upon request by customers. The wider variety of goods produced by welders enables them to cope with the fluctuations in return as compared to other entrepreneurs. The food and grocery shops constitute the smallest number because the activity is illegal.

In the market areas of the city centre, Kombayi and Mkoba high density suburb, vegetable and fruit vendors constitute the largest number of enterprises and the type of commodities they sell varies with season. In the wet season (October to February) they concentrate on selling green mealies, cabbages, tomatoes, onions, bananas, butternuts, onions, round-nuts, green beans, and mangoes and during the dry season the major commodities for sale include oranges, sweet potatoes, peanuts, bananas, cabbages, onions, and peas.

In general, most enterprises in the informal sector are family owned and skills are either acquired from the formal sector or were passed on within the family. The amount and types of goods produced vary with enterprises and depend on the seasonal demand of clients (affecting the type of waste 
TABLE 4: Sources of raw materials for the informal sector enterprises $\%$.

\begin{tabular}{|c|c|c|c|c|c|}
\hline Enterprise & Recycling & Waste dumps & Formal & Informal & Others \\
\hline Motor mechanics & 31 & 10 & 58 & - & - \\
\hline Welders & 15 & - & 58 & 27 & - \\
\hline Carpenters & - & - & 61 & 39 & - \\
\hline Tinsmith & - & - & 67 & 23 & - \\
\hline Plastics and drums & - & - & 1 & 99 & - \\
\hline Tyres & - & - & 77 & - & 23 \\
\hline Spare parts & - & - & - & - & 73 \\
\hline Food/vegetables & - & - & 65 & 35 & - \\
\hline Shoe repairs & - & 27 & 56 & 44 & - \\
\hline Upholstery & 33 & - & 30 & 33 & - \\
\hline Electrical repairs & - & - & 56 & 44 & - \\
\hline Metal working & - & 4 & 43 & 35 & - \\
\hline Dress making & 38 & - & 30 & 32 & - \\
\hline Brick moulding & - & 22 & 42 & 58 & - \\
\hline
\end{tabular}

generated by season's demands). There is also a strong and significant association between gender and type of enterprise as shown by the test result with $P<0.05$. The retail sector is dominated by women involved in flea markets, vegetable and fruit vending, food vending, and firewood sales and this is evidenced by the 150 females $(53.7 \%)$ out of the total 279 entrepreneurs in the retail category; the percentage of males involved is $46.3 \%$. There is a strong male gender bias in the repair, manufacturing, and construction sectors where men are involved in such activities as shoe repair, electronic repairs, electrical engineering, brick moulding, tinsmithing, steel fabrication, welding and grinding, carpentry, and milling.

3.2. Sources of Raw Materials. The sources of raw materials for the informal enterprises in Mambo, Monomotapa, Mkoba, Ascot, Kudzanai market, and Kombayi market include recycling activities, waste dumps, the formal sector, and informal traders. Other operators also obtain their raw materials from neighbouring countries such as clothing retailers who obtain most of their raw materials from Harare, Bulawayo, South Africa, Zambia and Tanzania, and Botswana. The sources of raw materials are indicated in Table 4.

A significant number of the motor mechanics (31\%) and of the welders $(15 \%)$ obtain their raw materials through recycling of their waste. Motor mechanics use parts of old car shells to repair other vehicles. Welders recycle small scrap metals for the repair of scotch carts and ploughs. The carpenters obtain their raw materials from reusing some leftover wood pieces and from suppliers such as Velmax, the Forestry Commission, DST Investments, and Dongo Investments in Gweru. Waste dumps are also a source of raw materials for the informal sector and in particular for the home industries at Mambo and Monomotapa. At Mambo and Monomotapa $25 \%$ and $27 \%$ of the spare parts enterprises indicated that they obtained some parts from waste dumps, while $13 \%$ and $18 \%$ of the motor mechanics use the same source, respectively. A study by Tevera [42] at Teviotdale waste dump located $7 \mathrm{~km}$ from Harare showed that the informal waste pickers collected scrap metal, containers, and planks from the dump for sale to the informal sector operators such as car breakers. In another study in Gaborone, Tevera noted that $2-10 \%$ of the weight of recovered material went to recycling companies while the remainder was used by the waste pickers or sold to the informal sector [43]. The situation in these two cities seems to be the same even today and typifies the current conditions in the informal sector of Gweru. Waste dumps are popular because the materials are obtained cheaply or at no cost at all. Waste dumps also provide a wide variety of recyclable materials and collection from the dumps offers several advantages. Retrieval of recyclable materials reduces the cost of maintaining the dumps and increases their life span. However, there is a need to establish a mechanism that would reduce transport costs for the waste pickers from the dump sites where they sell the collected materials.

Raw materials used by the home industries in Shamrock Park, Monomotapa, and Mkoba are also obtained from the formal sector. These raw materials include spare parts, engine oil, timber, metal sheets, tyres, and food items. This demonstrates the linkages between formal and informal sectors that have been observed since the 1970s [44]. Waste from the formal sector industries is sometimes diverted illegally by collecting companies to the Monomotapa and Mambo home industries where it is used as raw materials. This waste includes empty drums that previously contained hazardous substances such as methane. The hazardous substances can have physical, chemical, or biological characteristics that can place human health at risk or adversely affect the natural environment. Methane liquid is volatile and when introduced into the atmosphere it burns easily and also burns easily with any slight contact with fire [45]. The handling of hazardous raw materials by the home industries is dangerous not only to the area, but also to the neighbouring residential areas and shopping complexes.

3.3. Characteristics of Waste Generated in the Informal Sector Enterprises. Waste characterisation was based on solid 
TABLE 5: Categories used for solid waste characterization.

\begin{tabular}{|c|c|}
\hline Waste category & Types of waste \\
\hline Food and vegetable waste & $\begin{array}{l}\text { Wastes from handling, preparation, cooking, and eating of foods including fruits, maize cobs, chicken } \\
\text { waste, and bones. }\end{array}$ \\
\hline Paper & $\begin{array}{l}\text { Old and torn books, old newspapers, high grade paper (e.g., office and computer), old magazines, } \\
\text { mixed paper, and other nonusable paper. }\end{array}$ \\
\hline Cardboard & Old corrugated cardboard/kraft (recyclable). \\
\hline Plastics & $\begin{array}{l}\text { PETE (e.g., soft drink bottles and vegetable oil containers), HDPE (milk and water containers, and } \\
\text { detergent bottles), mixed plastics (commingled), plastics, and other plastics (PVC, LDPE, PP/5, and } \\
\text { PP/6). }\end{array}$ \\
\hline Glass & Flat glass, container glass, and beverage containers. \\
\hline Metals & $\begin{array}{l}\text { Mainly ferrous and nonferrous metals, aluminium or steel metals from tinsmith activities, empty } \\
\text { containers of paint, motor oil, thinners, and so forth. }\end{array}$ \\
\hline Wood & Wood shavings, waste building material and pallets, and small pieces of timber. \\
\hline Textiles & Pieces of cloth and fabric (synthetic and cotton) and threads. \\
\hline WEEE & $\begin{array}{l}\text { Waste from electronic repairs, damaged speakers, cell phones, expired elements, unfit wires, plates, } \\
\text { plugs, and used oil. }\end{array}$ \\
\hline Soil, builder's rubble & High amount of sand and organic matter, bricks, and few stones. \\
\hline Special waste & Hazardous waste in the enterprise waste stream such as batteries, oil, pieces of hair, and weaves. \\
\hline Miscellaneous & Wood ash, coal ash, room sweepings, and so forth. \\
\hline
\end{tabular}

TABLE 6: Average composition of waste generated in all the spatial locations (\% by weight).

\begin{tabular}{|c|c|c|c|c|c|}
\hline Waste category & Monomotapa & Shamrock Park & Mkoba & Kudzanai/Kombayi & Ascot \\
\hline Food/vegetables & 10.7 & 6.4 & 20.7 & 57.1 & 31.6 \\
\hline Paper & 6.4 & 6.0 & 10 & 8.9 & 10.7 \\
\hline Cardboard & 4.0 & 4.3 & 7.1 & 5.9 & 7.9 \\
\hline Plastics & 5.0 & 5.7 & 4.5 & 7.2 & 6.4 \\
\hline Glass & 3.5 & 5.0 & 5.0 & 3.0 & 3.3 \\
\hline Metals & 30.6 & 39.6 & 18.3 & 6.1 & 5.0 \\
\hline Wood & 10.4 & 12.1 & 13.0 & 1.9 & 17.0 \\
\hline Textiles & 9.0 & 1.0 & 8.0 & 2.0 & 4.0 \\
\hline Rubber & 5.0 & 3.0 & 4.0 & 1.0 & 5.6 \\
\hline WEEE & 2.7 & 2.0 & 3.0 & 1.0 & 1.4 \\
\hline Builder's rubble & 8.7 & 13.9 & 4.9 & 2.9 & 2.6 \\
\hline Miscellaneous & 4.0 & 1.0 & 1.5 & 3.0 & 4.5 \\
\hline Total & 100 & 100 & 100 & 100 & 100 \\
\hline
\end{tabular}

waste sampling, measurements, and questionnaire responses. The characteristics of the solid waste include generation rates, composition, biodegradability (how quickly waste can decompose through natural processes), and the uses to which the waste can be put. Table 5 shows the broad categories used in waste characterisation.

Average solid waste generated in all the informal sector enterprises is dominated by food and vegetable waste as shown in Table 6 . The food and vegetable waste dominates in areas that include Kudzanai and Kombayi market areas, Ascot high density suburb, and Mkoba high density suburb also in areas in and around market areas and bus ranks. High percentages of food waste are a result of the activities that dominate these areas which are associated with retail in vegetables and food hence generating large quantities of waste that include rotten vegetables and fruits as well as leftover foodstuffs from food preparation and retailing.

The significance of food waste is in their high degree of biodegradability since this entails the need for frequent collection to avoid odours and nuisance pests such as flies and cockroaches.

Metals are the most dominant type of waste generated at Monomotapa and Shamrock Park where the main activities involve metal working such as steel fabrication, welding, panel beating, mechanical and electrical engineering, panel beating, and tinsmiths. Ferrous and nonferrous metals are the major types of raw materials used in the workshops at Shamrock Park and Monomotapa. The main forms of solid waste generated in the workshops include swarf from the power hacksaws, centre latches, milling machines, and shapers 
as well as metal cut-offs in the form of pipes, sheet iron, channel lines, angle iron, and round iron bars. The waste from welding shops includes offcuts and iron fillings from the window sections; stubs, slug, and gas from welding rods; offcuts and iron fillings from flat bars and angle lines, door frame uprights, burglar bar rods, grinding, and cutting disks. These welding shops also produce waste in the form of used blades, blade pieces, and iron bars from hacksaw blades. Waste from tinsmith activities comprises mainly aluminium and steel scrap metals especially generated at Monomotapa, Mkoba, and Shamrock Park. The problem with waste from tinsmith activities is their sharpness and size. The sharp edges are dangerous to waste pickers and some scrap metals are large and contribute to the rapid filling of waste containers.

The paper and cardboard categories are dominant in the high density suburb of Ascot followed by the high density suburb of Mkoba. The paper and cardboard waste emanates from the old newspapers used as wrapping paper, brown wrapping paper, boxes used for packaging fruits and vegetables, paper from torn books, old invoices, and till slips. The informal sector enterprises experience problems in the storage and disposal of waste paper when collections are erratic and usually resort to burning the paper and this results in air pollution-related safety and health problems. However, the advantage of waste paper is that it is biodegradable and recyclable.

Plastics constitute a significant proportion $(7.2 \%$ and $6.4 \%$ ) of solid waste generated at Kudzanai market/bus rank and Ascot high density suburbs, respectively. The two major categories of plastics generated in the informal enterprises are clean commercial grade scrap and postconsumer scrap. Postconsumer scrap identified in the enterprises includes polyethylene terephthalate from soft drink bottles, salad dressings, and vegetable oil bottles. High density polyethylene comprises detergent and cooking oil bottles. Polypropylene plastic embraces battery casings especially in the motor mechanic enterprises at Monomotapa and Shamrock Park, closures and labels of bottles and containers, bread, and cheese wrappers as well as cereal box liners. Plastic waste from packaging for electronic components dominant in electrical engineering and repair workshops dominant at workshops at Monomotapa, Shamrock Park, and Ascot and fast food containers constitute polystyrene plastic.

Waste from carpentry, wood-fuel, and timber sales constitutes the second largest form of the solid waste generated from the enterprises at Ascot high density suburb (17\%) and third at Mkoba (13\%), Monomotapa (10.4\%), and Shamrock Park (12.1\%). The wood waste generated at Ascot emanates from both carpentry workshops and wood-fuel sales, that is, at Mkoba from carpentry workshops and at Shamrock Park from carpentry workshops and timber sales. The waste from carpentry comprises saw dust, wood shavings, and bark. The generation rates of these byproducts are very high and this contributes to the huge volume of waste produced by the enterprises. Waste from the carpentry workshops also comprises pieces of sewing thread, sand paper, tying cord, cotton lint, sacks, form rubber, vynea, and rexine as well as empty plastic bottles of varnish and glue. The advantage of waste generated in the carpentry, wood-fuel, and timber sales industries is that it is recyclable and also biodegradable meaning that it can be rapidly decomposed by natural processes. However, the wood waste presents problems of storage and disposal. Improper storage of sawdust results in becoming a respiratory irritant when the saw dust is inhaled. The saw dust can also be a problem when the wind blows it to adjacent enterprises such as those involved in spray painting as is the case at Monomotapa, Shamrock Park, and Mkoba. Another cause of concern emanates from the illegal burning of wood waste at the backyards of the carpentry and timber sales enterprises causing air pollution.

Rubber waste dominates at Ascot and Monomotapa comprising $5.6 \%$ and $5.0 \%$ of the total waste generated, respectively. The main form of rubber waste emanates from tyres. Although the tyres contribute a small fraction to the total waste produced they are not biodegradable and may contribute to the rapid filling of the disposal sites. Tyres can resurface later in the disposal sites and this is the reason why they have been banned in some areas of the United States. Burning of tyres is not the best method since it results in huge fumes of smoke that contribute to problems of air pollution. Builder's rubble is an important form of solid waste emanating from brick moulding activities due to increased construction activities in Gweru in the multicurrency era in Zimbabwe. Brick moulding enterprises are common at Shamrock Park (13.9\%) and at Shamrock $(8.7 \%)$ and such waste is heavy and bulky and requires large disposal sites and this presents problems for the authorities.

An emerging form of solid waste due to advances in technology as well as increased use of electrical gadgets in Gweru is waste electrical and electronic waste (WEEE) or electronic waste (e-waste). This type of waste emanates from the repair and disposal of large appliances such as refrigerators, microwaves, electrical heaters, and air conditioners; small home appliances such as toasters, coffee mixers, hair dryers, irons, and watches; IT and telecommunications equipment such as cell phones, laptops, personal computers, printers, photocopying equipment, calculators, and facsimiles. Ewaste also includes consumer equipment such as radios, televisions, and video cameras; lighting equipment such as fluorescent lamps; and electrical and electronic equipment such as sewing machines, welding equipment, gardening equipment, drills, and saws. This type of waste is most common in enterprises located at Monomotapa, Mkoba, Ascot, and Shamrock Park comprising 2.7\%, 3.0\%, and 2.0\% of the total waste, respectively. Special attention needs to be paid when dealing with WEEE because of the toxic substances it contains such as heavy metals, polybrominated diphenyl ethers, phthalates, and polyvinyl chloride. When managed improperly, the disposal of e-waste can adversely affect the environment and human health.

Analysis of standard deviations of individual means of waste categories revealed the following patterns (Table 7). The standard deviation for food and vegetable is the highest at 19.1 and this is due to the fact that the range between the highest average percentage and the lowest value is large. The highest percentage of vegetable waste generation is not surprisingly associated with the market areas of Kudzanai and Kombayi due to reasons explained above and the lowest 
TABLE 7: Descriptive statistics of mean waste \% generated in all the enterprises.

\begin{tabular}{lccccc}
\hline Waste category & Number of areas & Minimum & Maximum & Mean & Standard deviation \\
\hline Food/putrescibles & 5 & 6.40 & 57.00 & 26.0000 & 19.18658 \\
Cardboard & 5 & 4.00 & 7.50 & 5.7000 & 7.8000 \\
Paper & 5 & 6.00 & 10.70 & 5.7000 & 2.25278 \\
Plastic & 5 & 4.50 & 7.20 & 5.0000 & 1.03682 \\
Glass and ceramics & 5 & 3.00 & 5.00 & 19.9000 & .93541 \\
Metal & 5 & 5.00 & 39.60 & 11.1000 & 14.91392 \\
Wood & 5 & 2.00 & 8.00 & 5.7000 & 3.59464 \\
Textiles & 5 & 1.00 & 5.60 & 3.7000 & 1.78053 \\
Rubber & 5 & 1.00 & 3.00 & 2.1000 & .74162 \\
WEEE & 5 & 1.00 & 13.90 & 6.2000 & 4.23674 \\
Soil and builders rubble & 5 & 2.60 & 4.50 & 2.8000 & 1.52480 \\
Miscellaneous & 5 & 1.00 & & \\
\hline
\end{tabular}

percentage of vegetable and food waste is at Shamrock Park and understandably so due to the nature of activities here that are mainly metal working and have little to do with food vending or production. The other significant standard deviation is that of wood at 5.6 and the maximum value for this is associated with wood retailing activities at Ascot followed by Monomotapa where it is used as a source of fuel for domestic purposes such as cooking and heating. Most of the residents in Ascot and some parts of Monomotapa suburb are dwelling in newly constructed houses that have not been connected with electricity supplies and hence the common source of power has been wood-fuel and the informal sector has a ready market for their product. Another notable standard deviation from the mean is that of builders' rubble where the maximum percentage waste value is at Shamrock Park where brick moulding is a major activity and the minimum percentage waste generation value is at Ascot where the consumption rate of any leftover waste is high and the people in this area maximise on the use of any building material so as to save on costs. The standard deviations of the waste categories such as cardboard, paper, plastics, glass and ceramics, textiles, WEEE, and miscellaneous wastes from the mean values are quite low indicative of smaller deviations in the production of each of these categories of waste in the different spatial locations of the informal sector enterprises.

3.4. Biodegradability of Organic Waste. An important biological characteristic of the organic fraction of solid waste is its biodegradability. Almost all of the organic compounds can be converted to gases and relatively inert gases and inorganic solids [46]. The production of odours and generation of flies are related to the putrescible nature of organic materials found in solid waste such as food and vegetables. The volatile solids content, which is determined by its ignition at $550^{\circ} \mathrm{C}$, is usually used to determine the biodegradability of the organic fraction of solid waste. In the case of waste generated in the informal enterprises, the use of volatile solids in describing biodegradability could be misleading because some of the organic constituents of the solid waste are highly volatile, but low in biodegradability. Such wastes include newsprint and certain plant trimmings. The lignin content can be used to establish the biodegradable fraction. Lignin is a polymeric material containing aromatic rings with methoxyl groups $\left(-\mathrm{OCH}_{3}\right)$ the chemical nature of which is still unknown. It is present in some paper products such as newsprint and fibreboard.

Wastes with a high lignin content such as newsprint are significantly less biodegradable than other wastes like food wastes and vegetable wastes, office paper, and wood wastes. Table 7 shows the descriptive statistics of waste categories generated in all the spatial locations of the enterprises and confirms that the maximum value of food wastes is $57.1 \%$ and Table 9 also confirms that the spatial location associated with this value is Kudzanai. This thus provides opportunities for using waste generated at Kudzanai and areas such as Ascot and Mkoba market areas for composting as a way of diverting waste from the landfills. Another type of solid waste with a low lignin content and high amount of volatile solids is office paper and descriptive statistics in Table 7 show that the largest value of paper waste is $10.7 \%$ and this is at Ascot followed by Mkoba (10\%) and Kudzanai (8.9\%). Wood wastes are characterised by a relatively high biodegradable fraction of 0.72 due to the low lignin content of volatile solids of 4.1. The enterprises that could take advantage of the biodegradability of the wood wastes in managing waste include those with the highest value of $17 \%$ (Table 8) at Ascot where wood-fuel sales is a major activity together with carpentry followed by Mkoba (13\%) where carpentry is an important activity.

3.5. Inferential Statistics for Waste Characterization in the Informal Enterprises. Descriptive statistics are an essential data analysis tool for elementary description of maximum, minimum, average values, standard deviations of waste types generated in the five spatial areas under focus in this study. They do not, however, provide the level of significance of the variations and it is vital to undertake further statistical analysis of variations by spatial location as well as seasonal variations of waste generation.

3.5.1. ANOVA Results for Seasonal Variation in Sample Composition. Table 8 shows the mean composition of solid waste generated in the informal enterprises in the dry season. The 
TABLE 8: Composition of waste generated in the dry season (\% by weight).

\begin{tabular}{|c|c|c|c|c|c|}
\hline Waste category & Monomotapa & Shamrock Park & Mkoba & Kudzanai/Kombayi & Ascot \\
\hline Food/vegetable waste & 9 & 9 & 18 & 51 & 29 \\
\hline Paper & 5 & 7 & 11 & 9 & 11 \\
\hline Cardboard & 4 & 4 & 9 & 6 & 6 \\
\hline Plastics & 5 & 5 & 4 & 8 & 7 \\
\hline Glass & 4 & 3 & 6 & 3 & 3 \\
\hline Metals & 31 & 36 & 19 & 7 & 5 \\
\hline Wood & 8 & 14 & 12 & 2 & 20 \\
\hline Textiles & 10 & 1 & 7 & 2 & 4 \\
\hline Rubber & 4 & 3 & 4 & 1 & 5 \\
\hline WEEE & 3 & 2 & 3 & 1 & 2 \\
\hline Builder's rubble & 14 & 15 & 6 & 7 & 3 \\
\hline Miscellaneous & 3 & 1 & 1 & 3 & 5 \\
\hline Total & 100 & 100 & 100 & 100 & 100 \\
\hline
\end{tabular}

TABLE 9: Composition of waste generated in the wet season (\% by weight).

\begin{tabular}{|c|c|c|c|c|c|}
\hline Waste category & Monomotapa & Shamrock Park & Mkoba & Kudzanai/Kombayi & Ascot \\
\hline Food/vegetable & 11 & 17 & 23 & 63 & 34 \\
\hline Paper & 7 & 5 & 9 & 4 & 10 \\
\hline Cardboard & 4 & 5 & 6 & 5 & 8 \\
\hline Plastics & 5 & 6 & 5 & 6 & 6 \\
\hline Glass & 3 & 7 & 4 & 3 & 4 \\
\hline Metals & 29 & 43 & 18 & 6 & 5 \\
\hline Wood & 13 & 12 & 14 & 2 & 14 \\
\hline Textiles & 7 & 1 & 9 & 2 & 4 \\
\hline Rubber & 6 & 3 & 4 & 1 & 6 \\
\hline WEEE & 1 & 2 & 3 & 1 & 3 \\
\hline Builder's rubble & 9 & 11 & 3 & 4 & 2 \\
\hline Miscellaneous & 5 & 1 & 2 & 3 & 4 \\
\hline Total & 100 & 100 & 100 & 100 & 100 \\
\hline
\end{tabular}

main components of the waste stream include food and vegetable wastes at Monomotapa, Ascot, and Mkoba (51\%, $29 \%$, and 185, resp.), metals at Shamrock Park, Monomotapa, and Mkoba (36\%, 31\%, and 19\%, resp.), and paper at Mkoba, Ascot, and Kudzanai $(11 \%, 11 \%$, and 9\%, resp.). There are variations in the amounts of solid waste generations generated in the wet season as shown in Table 8 .

Table 9 shows that in the wet season there is an increase in the amount of putrescible solid waste in the form of food and vegetable waste generated in the informal sector. This is especially so in the case of Kudzanai, Ascot, Mkoba, and Shamrock Park. The increase is attributed to increased availability of vegetables, fruit, and food crops such as maize due to the onset of the wet season as well as the festive season as well. Metal production also increases in the wet season at Shamrock Park and so do carpentry activities producing more waste at Monomotapa due to increased demand for furniture towards the end of the year. Other types of solid waste such as builder's rubble show a general decrease in the wet season in all spatial areas due to reduced construction and building activities. The reduction in the amount of builder's rubble is a result of the effect of rainfall and company closures during the December holidays. The significance in the variations in waste generation by season was verified using one-way ANOVA.

A one-way ANOVA was suitable to test the effect of seasonal variations on sample composition. This technique is suitable because it allows testing if the means being compared are different (varied) from each other. The one-way ANOVA was especially useful in this comparison because it could compare means irrespective of whether the dependent variable was interval or ordinally scaled data.

Analysis of the effect of seasonal variations on sample composition was based on an initial hypothetical premise summarised by the following null hypothesis:

$\mathrm{H}_{0}$ : the mean values of material components in the samples were the same in the dry and wet seasons.

ANOVA test results showed that the means of two material components, dry season plastic and dry season metal, differed or varied significantly within the dry season itself and in the dry season compared to the wet season figures. The 
null hypothesis $\left(\mathrm{H}_{0}\right)$ is rejected and the alternative hypothesis $\left(\mathrm{H}_{1}\right)$ that the means of certain components of samples varied significantly is retained. This variation is calculated as the ratio of mean square deviation between seasons and within season, otherwise known as the Fisher $(F)$ statistic. The extent or The extent of significance is shown by the $P$ value, where $P<0.05$ level of variation is said to be statistically significant.

There is also a significant effect of season on

dry season plastic $[F=20.6: P=0.046]$; this means that there was more plastic waste in the dry season than the wet season;

dry season metal $[F=52.19: P=0.19]$; this shows that there was more metal in the dry season than the wet season.

Significance values $(P)$ in this case are a two-tailed probability that the magnitude of the test statistic is a chance result. A confidence level of 0.05 is assumed throughout this thesis. Where $P<0.05$, this indicates a $95 \%$ confidence level that perceived variation is not by chance error. The remaining nine food and vegetable wastes, paper, cardboard, glass, wood, textiles, rubber, WEEE, soil, and builder's rubble and miscellaneous waste show no significant variations over the seasons or instances of variations could be ascribed to chance occurrence.

The analysis of variance of the effect of season on spatial variation of sample composition was based on the following null hypothesis:

$\mathrm{H}_{0}$ : season has no significant impact on the spatial variation of sample composition.

ANOVA test results show that there is significant difference in the mean values of sample composition in the following spatial areas, that is, Shamrock Park in the wet and dry seasons, Monomotapa wet and dry seasons, Mkoba wet season only, Kudzanai wet and dry season, and Ascot in the wet and dry seasons. It is in Mkoba during the dry season where there is no significant variation in sample composition.

3.5.2. ANOVA Results for the Effect of Sampling Location on Sample Composition. The analysis of variance of the effect of spatial location on sample composition was based on an initial hypothetical premise summarized by the following null hypothesis:

$\mathrm{H}_{0}$ : the mean values of material components of waste samples were the same in all sampling zones.

ANOVA test results showed that there was significant difference in the mean values of material components in four of the five sampling locations and these are Monomotapa, Shamrock Park, Kudzanai, and Ascot. The null hypothesis is thus rejected and the alternative hypothesis that the means of certain components of the samples vary with spatial location is retained. There was a significant effect of sampling location at

Kudzanai $F=77.595: P=0.000$; Ascot $F=23.748$ : $P=0.012$; Shamrock Park $F=194.075: P=0.000$; and Monomotapa $F=11.222: P=0.036$.
These results indicate that spatial location has a significant effect on sample composition in these spatial locations. Spatial location had no significant statistical effect on sample composition at Mkoba or instances of variation could be ascribed to chance occurrence.

The total amount of solid waste generated by all enterprises at Monomotapa, Mambo, and Mkoba home industries was estimated to be 12.4 tonnes per week. The per capita waste generation calculated using the whole population of operators and their employees which is approximately 2000 persons gives an average of $0.885 \mathrm{~kg} /$ capita/day. In Gweru, the per capita waste generation for formal industries is not known and therefore it is difficult to compare the informal sector per capita waste generation with that of the formal sector. However, in the home industries in Monomotapa, Mambo, and Mkoba the per capita solid waste generation is greater than the domestic per capita waste generation $(0.53 \mathrm{~kg} / \mathrm{capita} /$ day $)$ of Gweru. This may be due to the high waste generation rates of industrial activities.

\section{Conclusion}

In order to come up with a sustainable and comprehensive waste management plan for the informal sector of Gweru, an up-to-date database on the composition and characteristics of the waste is a primary requirement. In the informal enterprises of Gweru, on average $64 \%$ of the solid waste generated is biodegradable. The majority of environmental and public health problems associated with waste generated in the informal sector enterprises are caused by the biodegradable components. In this survey the biodegradable fraction was assessed in terms of food and vegetable wastes from the informal sector enterprises in Monomotapa, Mkoba, and Ascot, Shamrock Park, and Kudzanai/Kombayi market. The average per capita generation of biodegradable waste was found to vary from 260 to $470 \mathrm{~g} /$ day. Short term biodegradable waste such as food and vegetable accounted for an average of $62 \%$ and long term biodegradable (incinerable) wastes including paper, dry leaves, textiles, rubber, and leather products accounted for $36 \%$. The high biodegradable fraction of the waste supports composting as a potential option. The composition of nonbiodegradable fraction (22.6\%) included inert materials arising out of soil and rubble generated in the enterprises. The high inert content increases the waste density between 332 and $571 \mathrm{~kg} / \mathrm{m}^{2}$. The recyclable components were only about $11.6 \%$ and the hazardous component was very little $(0.33 \%)$. The dry recyclables such as paper, plastics, metal, and glass are very low due to the informal practice of waste reduction, reuse, and recycling with the involvement of the rag pickers, itinerant buyers, and dealers of recyclables.

\section{Conflict of Interests}

The author declares that there is no conflict of interests regarding the publication of this paper.

\section{Acknowledgments}

The author acknowledges the financial assistance provided by the Research and Post Graduate office of the Midlands State 
University for undertaking this research. Informal sector operators in all the spatial areas of Gweru involved in this study are also thanked for their willingness in providing information relating to their activities.

\section{References}

[1] R. Afroz, K. Hanaki, and K. Hasegawa-Kurisu, "Willingness to pay for waste management improvement in Dhaka city, Bangladesh," Journal of Environmental Management, vol. 90, no. 1, pp. 492-503, 2009.

[2] Eurostat, Waste Generated in Europe. Data 1985-1997, Luxembourg Office for Official Publications of the European Communities, 2009.

[3] A. Gallardo, M. D. Bovea, F. J. Colomer, M. Prades, and M. Carlos, "Comparison of different collection systems for sorted household waste in Spain," Waste Management, vol. 30, no. 12, pp. 2430-2439, 2010.

[4] J. Krook, N. Svensson, and M. Eklund, "Landfill mining: a critical review of two decades of research," Waste Management, vol. 32, no. 3, pp. 513-520, 2012.

[5] C. Liu and X.-W. Wu, "Factors influencing municipal solid waste generation in China: a multiple statistical analysis study," Waste Management and Research, vol. 29, no. 4, pp. 371-378, 2010.

[6] N. J. G. J. Bandara, J. P. A. Hettiaratchi, S. C. Wirasinghe, and S. Pilapiiya, "Relation of waste generation and composition to socio-economic factors: a case study," Environmental Monitoring and Assessment, vol. 135, no. 1-3, pp. 31-39, 2007.

[7] A. O. Afon, "Informal sector initiative in the primary subsys-tem of urban solid waste management in Lagos, Nigeria," Habitat International, vol. 31, no. 2, pp. 193-204, 2007.

[8] L. Aye and E. R. Widjaya, "Environmental and economic analyses of waste disposal options for traditional markets in Indonesia," Waste Management, vol. 26, no. 10, pp. 1180-1191, 2006.

[9] J. R. Barton, I. Issaias, and E. I. Stentiford, "Carbon-making the right choice for waste management in developing countries," Waste Management, vol. 28, no. 4, pp. 690-698, 2008.

[10] L. Dahlén and A. Lagerkvist, "Methods for household waste composition studies," Waste Management, vol. 28, no. 7, pp. 1100-1112, 2008.

[11] N. Matete and C. Trois, "Towards Zero Waste in emerging countries-a South African experience," Waste Management, vol. 28, no. 8, pp. 1480-1492, 2008.

[12] M. Sharholy, K. Ahmad, G. Mahmood, and R. C. Trivedi, "Municipal solid waste management in Indian cities-a review," Waste Management, vol. 28, no. 2, pp. 459-467, 2008.

[13] C. Chiemchaisri, J. P. Juanga, and C. Visvanathan, "Municipal solid waste management in Thailand and disposal emission inventory," Environmental Monitoring and Assessment, vol. 135, no. 1-3, pp. 13-20, 2007.

[14] S. D. Mancini, A. R. Nogueira, D. A. Kagohara, J. A. S. Schwartzman, and T. de Mattos, "Recycling potential of urban solid waste destined for sanitary landfills: the case of Indaiatuba, SP, Brazil," Waste Management and Research, vol. 25, no. 6, pp. 517523, 2007.

[15] A. M. Troschinetz and J. R. Mihelcic, "Sustainable recycling of municipal solid waste in developing countries," Waste Management, vol. 29, no. 2, pp. 915-923, 2009.

[16] S. J. Burnley, "A review of municipal solid waste composition in the United Kingdom," Waste Management, vol. 27, no. 10, pp. 1274-1285, 2007.
[17] D. C. Walsh, "Urban residential refuse composition and generation rates for the 20th century," Environmental Science and Technology, vol. 36, no. 22, pp. 4936-4942, 2002.

[18] L. Sokka, R. Antikainen, and P. E. Kauppi, "Municipal solid waste production and composition in Finland-Changes in the period 1960-2002 and prospects until 2020," Resources, Conservation and Recycling, vol. 50, no. 4, pp. 475-488, 2007.

[19] B. Dyson and N.-B. Chang, "Forecasting municipal solid waste generation in a fast-growing urban region with system dynamics modeling," Waste Management, vol. 25, no. 7, pp. 669-679, 2005.

[20] C.-C. Yu and V. MacLaren, "A comparison of two waste stream quantification and characterization methodologies," Waste Management and Research, vol. 13, no. 4, pp. 343-361, 1995.

[21] S.-S. Chung and C.-S. Poon, "Characterisation of municipal solid waste and its recyclable contents of Guangzhou," Waste Management and Research, vol. 19, no. 6, pp. 473-485, 2001.

[22] K. Yuan, H. Xiao, and X. Li, "Development and application of municipal solid waste incineration in China," Nengyuan Gongcheng, vol. 5, pp. 43-46, 2008.

[23] D. Zhu, P. H. Asnani, C. Zurbrugg, S. Anapolosky, and S. Mani, Improving Solid Waste Management in India: A Source Book for Policy Makers and Practitioners, World Bank, Washington, DC, USA, 2009.

[24] S.-S. Chung, "Using plastic bag waste to assess the reliability of self-reported waste disposal data," Waste Management, vol. 28, no. 12, pp. 2574-2584, 2008.

[25] K. Parizeau, V. Maclaren, and L. Chanthy, "Waste characterization as an element of waste management planning: lessons learned from a study in Siem Reap, Cambodia," Resources, Conservation and Recycling, vol. 49, no. 2, pp. 110-128, 2006.

[26] R. K. Henry, Z. Yongsheng, and D. Jun, "Municipal solid waste management challenges in developing countries-Kenyan case study," Waste Management, vol. 26, no. 1, pp. 92-100, 2006.

[27] V. E. Manga, O. T. Forton, and A. D. Read, "Waste management in Cameroon: a new policy perspective?" Resources, Conservation and Recycling, vol. 52, no. 4, pp. 592-600, 2008.

[28] T. C. Nzeadibe, "Solid waste reforms and informal recycling in Enugu urban area, Nigeria," Habitat International, vol. 33, no. 11, pp. 93-99, 2009.

[29] L. Parrot, J. Sotamenou, and B. K. Dia, "Municipal solid waste management in Africa: strategies and livelihoods in Yaoundé, Cameroon," Waste Management, vol. 29, no. 2, pp. 986-995, 2009.

[30] S. Jerie, "Sound sanitary landfilling: a sustainable option for waste disposal in Harare and Gweru, Zimbabwe," OSSREA Bulletin, vol. 2, no. 3, pp. 78-87, 2005.

[31] S. Jerie, "Environmental problems in Gweru and Kwekwe, Zimbabwe: a focus on domestic solid waste management," UNISWA Research Journal of Agriculture, Science and Technology, vol. 9, no. 2, pp. 179-185, 2006.

[32] S. Jerie, "Gender and solid waste management in the informal sector of Bulawayo, Zimbabwe," The Dyke, vol. 5, no. 1, pp. 4664, 2011.

[33] J. Johannes, M. Malin, J. Ulla-Maija, L. Magareta, W. Nina, and K. Hannele, Directions of Future Developments in Waste Recycling, Technology, 2012.

[34] G. Wehenpohl and M. Kolb, "The economic impact of the informal sector in solid waste in developing countries," in Proceedings of the 11th International Waste Management and Landfill Symposium (Sardina '07), Cagliari, Italy, 2007. 
[35] M. Medina, The Informal Recycling Sector in Developing Countries, Note no. 44, The World Bank, Public-Private Infrastructure Advisory Facility, Washington, DC, USA, 2008.

[36] A. Scheinberg, S. Spies, M. H. Simpson, and A. P. J. Mol, Economic Aspects of Solid Waste Management, GIZ/CWG, 2010.

[37] P. Gerdes and E. Gunsilius, The Waste Experts: Enabling Conditions for informal Sector Integration in Solid Waste Management-Lessons Learnt from Brazil, Egypt and India, Partnerships for Recycling Management, Eschborn, Germany, 2010.

[38] K. Hetz, J. G. Paul, J. C. Alfaro, and A. Lemke, “The informal recycling market in Ormoc City, Philippines: evaluation of options to enhance resources recovery and to reduce GHG emissions," in Proceedings of the International SWM Conference on Moving towards Sustainable Resource Management, Hong Kong, May 2011.

[39] SWAPP, Economic Aspects of Informal Sector Activities in Solid Waste Management, Association of the Philippines (SWAPP), Makati City, Philippines, 2006.

[40] L. F. Diaz, L. L. Eggerth, and G. M. Savage, Management of Solid Wastes in Developing Countries, IWWG Task Group on Waste Management in Developing Countries, CISA, 2007.

[41] CWG and GIZ, The Economics of the Informal Sector in Solid Waste Management Collaborative Working Group on Solid Waste Management (CWG) and Deutsche Gesellschaft Fuer Internationale Zusammenarbelt (GIZ), Series no. 5, CWG Publication, Eschborn, Germany, 2001.

[42] D. S. Tevera, "Waste recycling as a livelihood in the informal sector: the Case of Harare's Teviotdale garbage dump scavengers in Harare," in Zinyama, University of Zimbabwe Publications, Harare, Zimbabwe, 1993.

[43] D. S. Tevera, "Dump scavenging in Gaborone, Botswana: anachronism or refuge occupation of the poor?" Geografiska Annaler B, vol. 76, no. 1, pp. 21-32, 1994.

[44] C. O. N. Moser, "Informal sector or petty commodity production: dualism or dependence in urban development?" World Development, vol. 6, no. 9-10, pp. 1041-1064, 1978.

[45] J. B. Nebel, Environmental Science, the Way the World Works, Prentice Hall, New York, NY, USA, 3rd edition, 1990.

[46] G. Tchobanoglous, H. Theisen, and S. Vigil, Integrated Solid Waste Management Issues, McGraw Hill, New York, NY, USA, 1993. 

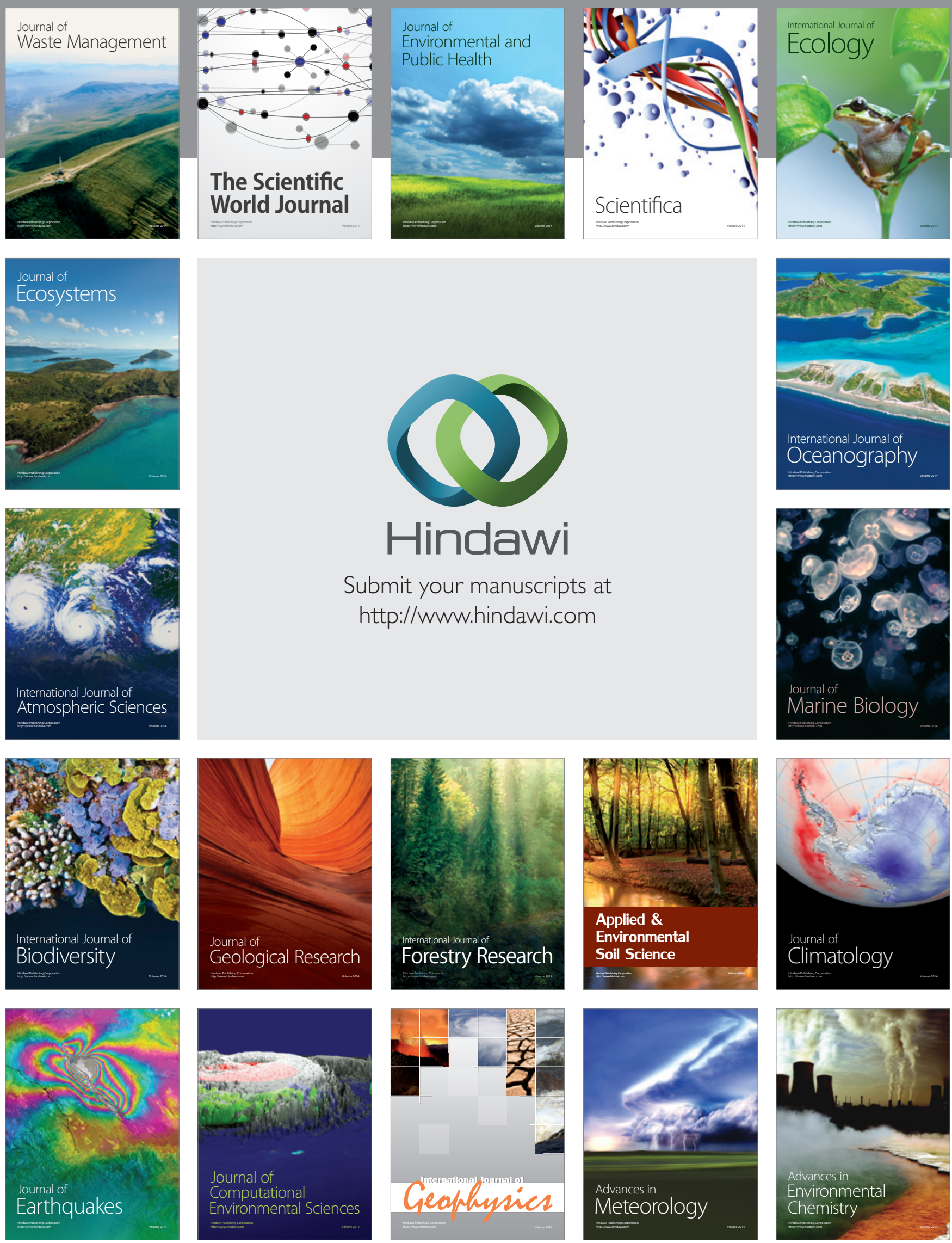